\title{
ISOLATION OF SPOROTHRIX SCHENKII FROM THE NAILS OF HEALTHY CATS
}

\author{
Lorena Leonardo de Souza ${ }^{1 *}$; Patrícia da Silva Nascente²; Márcia Oliveira Nobre'; Ana Raquel Mano Meinerz²; \\ Mário Carlos Araújo Meireles ${ }^{1}$
}

${ }^{1}$ Faculdade de Veterinária, Universidade Federal de Pelotas, Pelotas, RS, Brasil; ${ }^{2}$ Faculdade de Veterinária, Universidade Federal do Rio Grande do Sul, Porto Alegre, RS, Brasil

Submitted: October 08, 2004; Returned to authors for corrections: May 04, 2005; Approved: April 19, 2006

\section{SHORT COMMUNICATION}

\begin{abstract}
Many cases of sporotrichosis in cats were diagnosed in the town of Rio Grande, RS, Brazil, caused mainly by inoculation due to scratches. In this work, we evaluated the frequency of Sporothrix schenckii in the nails of healthy cats living together with cats showing clinical sporotrichosis. The isolation of the fungus was carried out pressing unwashed nails of the forelimbs of 24 cats (48 paws) directly onto the surface of Mycobiotic Agar in Petri dishes. S. schenckii was isolated from seven (29.1\%) cats. The procedure for isolation of the fungus was simpler than methods that require sedation and cuts of the nails.
\end{abstract}

Key words: sporotrichosis, cats, nails, Sporothrium schenckii

Sporotrichosis is a subcutaneous mycosis caused by Sporothrix schenckii, a dimorphic fungus widely dispersed in nature, especially in temperate and tropical climates. This mycosis is generally due to the implantation of the fungus Sporothrix schenckii spores in the subcutaneous tissue. Feline sporotrichosis has been described in the literature and its importance as a source of human infection has been reported, especially among pet owners and veterinarians $(4,5,8,9)$. In cats, sporotrichosis causes ulcerous lesions in the head, face, ear extremes, tail and anterior and posterior members. Ascendent lynphangitis may be developed from the primary wound and rarely disseminates into other organs $(2,14)$.

Investigation accomplished in our laboratory described a high number of cases of sporotrichosis in cats residing in the same household (12). In Rio de Janeiro, even an epidemic of sporotrichosis in cats was described, and the fungus Sporothrix schenckii was isolated from the nails of sick cats. This leads us to conclude that inoculation of Sporothrix schenckii by scratching may represent a significant form of transmission of this mycosis and zoonotic potential of feline sporotrichosis (14).
Recents publications, all over the world, describe the domestic cat (Felis catus) as one of the sources of infection of the fungus Sporothrix schenckii (1,4,5,7,8,11-14). The zoonotic potential, from cat to man, is characterized by the high number of microorganisms found in the lesions of sick cats and by the habit that the felines have to scratch $(5,8,12-15)$.

In this study, the infectious agent Sporothrix schenckii was investigated in the nails of clinically healthy cats in the city of Rio Grande (RS), South area of Brazil. The isolation of the fungus was accomplished at the Laboratory of Mycology at the Faculty of Veterinary of the Federal University of Pelotas UFPEL, RS, Brazil.

The decision of investigating the presence of the fungus Sporothrix schenckii in the nails of cats appeared when a sporotrichosis outbreak was diagnosed in a population of 90 cats in the city of Rio Grande (RS), South area of Brazil (12).

The study was carried out with 24 cats of a community constituted of 90 cats residing in the same household and presenting frequent contact with soil and vegetation and the habit to sharpen their nails in the trees. For isolation of

*Corresponding Author. Mailing address: Av. República, 224, Areal. 96077-230, Pelotas, RS, Brasil; Tel.: (+5553) 228- 4498. E-mail: souza1106@hotmail.com. 
Sporothrix schenckii, nail impressions were obtained from the right and left thoracic members of 24 healthy cats (48 paws) that lived together with cats showing clinical sporotrichosis. To obtain the samples, the digital torulos, located behind the distal extremities of the metacarpi bones (cushions palmate), were pressed for the exhibition of the nails. Once exposed, they were printed directly into the culture media (Fig. 1) without previous wash or any other antiseptic procedure. The culture media was Mycobiotic Agar (DIFCO, Detroit, MI, USA). The plates were incubated at $25^{\circ} \mathrm{C}$ for 10 days and the identification of the isolates was based on the macroscopic and microscopic characteristics of the fungus. Later on, the isolates were re-plated and incubated at $37^{\circ} \mathrm{C}$ to confirm the dimorphism.

Sporothrix schenckii was isolated from the nails of seven (29.1\%) cats. Besides colonies of Sporothrix schenckii, other fungi and bacterial colonies were also obtained. The suspected Sporothrix schenckii colonies on Mycobiotic Agar presented a pleated surface, and a creamy color that blackened later on. The microscopic exam indicated fine septedes and hyaline

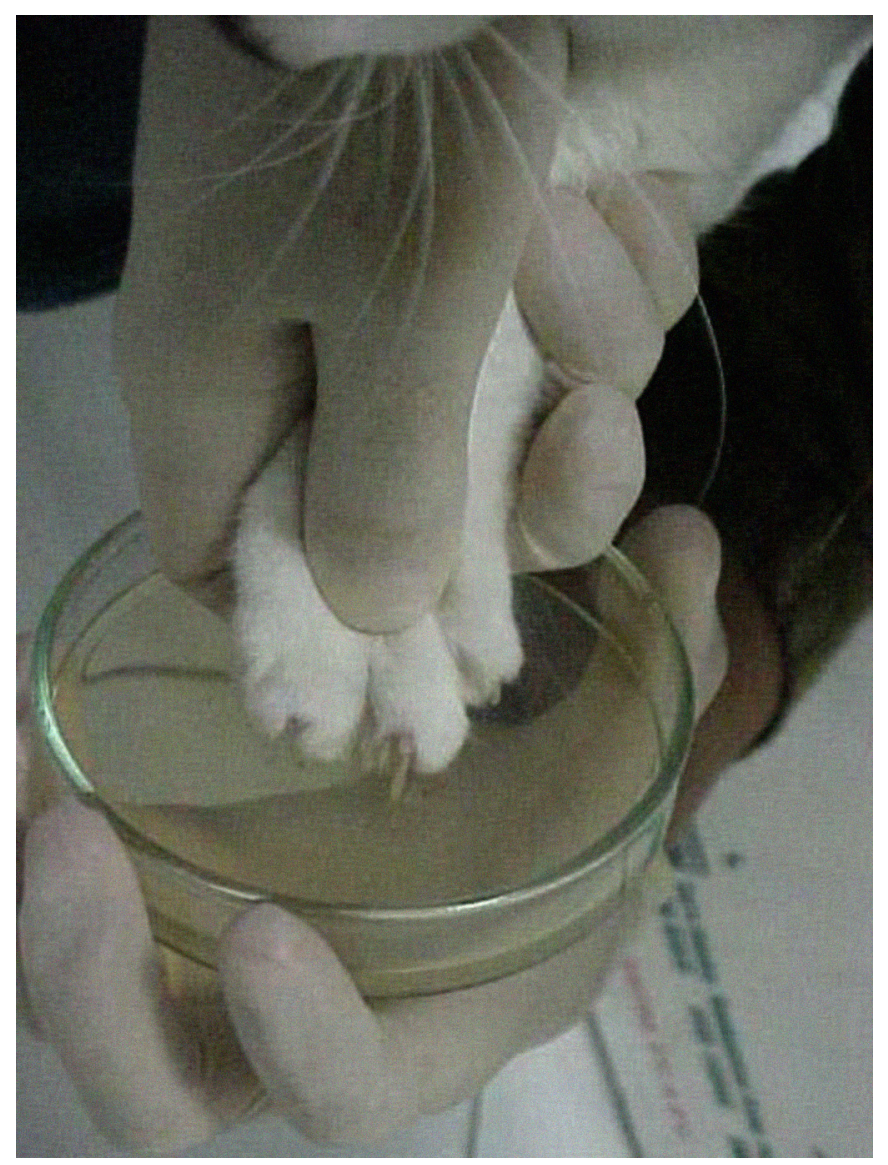

Figure 1. Technique to sample the nails of cats for detection of Sporothrix schenckii. hyphae, with piriform conids disposed along the hyphas, like "daisies".

The result demonstrates the importance of clinically healthy cats in the dynamics of the sporotrichosis, and confirms the importance of this species in the epidemiology of the disease as carrier of the fungus through the nails $(5,8,12-15)$.

Schubach et al., 2004 (15) recently reported the isolation of Sporothrix schenckii from the nails of sick cats, which were sedated and submitted to skin biopsy. The extremities of the nails were cut for subsequent cultivation. In this work a simpler method is described, which is more practical and effective, because sedation and, previous wash or cut of the nails of the cats are not necessary.

\section{ACKNOWLEDGMENTS}

Tha authors thank CAPES and CNPq for financial support.

\section{RESUMO}

\section{Isolamento de Sporothrix schenckii de unhas de gatos sadios}

Um número elevado de casos de esporotricose em gatos foi diagnosticado na cidade de Rio Grande/RS/Brasil, e na maioria dos animais, a doença ocorreu após inoculação do fungo a partir de arranhões. Nesse estudo, avaliou-se a freqüência de Sporothrix schenckii nas unhas de gatos saudáveis que conviviam com gatos com esporotricose. $\mathrm{O}$ isolamento do fungo foi realizado a partir da impressão das unhas dos membros torácico direito e esquerdo, de 24 gatos (48 patas), diretamente em placas de Petri com Agar Mycobiotic sem lavagem prévia das unhas. S. schenckii foi isolado de sete gatos $(29,1 \%)$. O procedimento adotado para o isolamento do fungo foi mais simples que os procedimentos que requerem sedação e corte das unhas do animal.

Palavras-chave: esporotricose, gatos, unhas

\section{REFERENCES}

1. Andrade, B.P.J. de; Brustein, R.; Rodrigues, M.R. Esporotricose: Quando gatos e proprietários são infectados. In: Congresso Internacional de Medicina Felina, I, Rio de Janeiro (Brasil), Anais, 1999, p.20.

2. Baroni, F.A.; Campos, S.G.; Direito, G.M. Esporotricose em gatos (Descrição de um caso). Rev. Bras. Med. Veterin., 20(1), 25-27, 1998.

3. Costa, D.M.; Moreira, N.S.; Toledo-Piza, E.; Ribeiro, L.A.F. Esporotricose felina: Relato de quatro casos no Rio de Janeiro. Rev Bras. Ciên. Vet., 7, 131, 2000.

4. Liparisi, F.; Tortelly, R.; Carvalho, E.C.Q.; Mandarino, M.; Calixto, R.; Florido, P.S. Importância zoonótica da esporotricose felina. In. Congresso Internacional de Medicina Felina, II, Rio de Janeiro (Brasil), Anais, 2001, p.25 
5. Lipstein-Kresch, E.; Isemberg, H.D.; Singer, C.; Cooke, O.; Greenwald, R.A. Disseminated Sporothrix schenckii infection with arthritis in a patient with acquired immunodeficiency syndrome. $J$. Rheumatol., 12, 805-808, 1985.

6. Londero, A.T.; Ramos, C.D. Esporotricose no Rio Grande do Sul. Três décadas de observação. An. Bras. Dermat., 64, 307-310, 1989.

7. Marques, S.A.; Franco, S.R.V.S.; Camargo, R.M.P.; Dias, L.D.F.; Haddad-Júnior, V.; Fabris, V.E. Esporotricose do gato doméstico (Felis catus): transmissão humana. Rev. Inst. Med. Trop. São Paulo, 35, 327-330, 1993.

8. Marques, A.S.; Camargo, R.M.P. de; Haddad-Junior, V.; Marques, M.E.A.; Franco, S.R.V.S.; Rocha, N.S. Human sporotrichosis: transmitted by feline. An. Bras. Dermat., 76, 559-562, 1998.

9. Morgan, M.; Reves, R. Invasive sinusitis due to Sporothrix schenckii in a patient with AIDS. Clin. Infect. Diseases, 23, 1319-1320, 1996.

10. Nakano, H.; Suzuki, A.; Tojima, H.; Imahashi, M.; Kashiyama, T.; Honda, A.; Watanabe, A.; Mizuguschi, K.; Kamei, K. A case of primary pulmonary sporotrichosis. Nihon Kyobu Shikkan Gakkai Zasshi, 27, 220-224, 1989.
11. Reed, K.D.; Moore, M.F.; Geiger, G.E.; Stemper, M.E. Zoonotic Transmission of Sporotrichosis: case report and review. Clin. Infect. Diseases, 16, 384-387, 1993.

12. Souza, L.L. Sporothrix scheckii: Estudo epidemiológico em populações de gatos. Pelotas: Universidade Federal de Pelotas. 2001, 36p. Dissertação (Mestrado em Medicina Veterinária), Faculdade de Veterinária. Universidade Federal de Pelotas, 2001.

13. Souza, M.D.M.; Peres, M.R.; Bernardes, M.A.A.G.; Guimarães, L.O.F.; Gazeta, G.S.; Gitti, C.B.; Aboud-Dutra, A.E. Esporotricose felina e a importância zoonótica - Relato de caso no Rio de Janeiro, RJ, Brasil. Rev. Bras. Ciên. Vet., 7, 131, 2000.

14. Schubach, T.M.P.; Valle, A.C.F.; Gutierrez-Galhardo, M.C.; Monteiro, P.C.F.; Reis, R.S.; Zancopé-Oliveira, R.M.; Marzochi, K.B.F.; Schubach, A. Isolation of Sporothrix schenckii from the nails of domestic cats (Felis catus). Med. Micol., 39, 147-149, 2001.

15. Schubach, T.M.; Schubach, A.; Okamoto, T.; Barros, M.B.; Figueiredo, F.B.; Cuzzi, T.; Fialho-Monteiro, P.C.; Reis, R.S.; Perez, M.A.; Wanke, B. Evaluation of an epidemic of sporotrichosis in cats: 347 cases (1998-2001). J. Am. Vet. Med. Assoc., 15, 224(10),1623-1629, 2004. 